\title{
Web Streaming TVUPI as Modern Communication Model and Contribution to Learning Quality
}

\author{
DENI DARMAWAN \\ Jurusan Kurikulum dan Teknologi Pendidikan, Fakultas Pendidikan, Universitas Pendidikan Indonesia \\ e-mail:ddarmawan@upi.edu
}

\begin{abstract}
Web streaming TVUPI as a modern campus communication model developed for 2 years through design, testing, revision, dissemination, and measuring its contribution to the quality of learning. Through modern campus communication model, it is expected that all parties both on national and international scale would be able to interact quickly and appropriately in meeting the information needs of UPI. Development of TVUPI as a communication model involves scholars who support, particularly, from the communication science. Thus, practically and scientifically, Web streaming TVUPI is qualified for a modern campus communication model. The method used is Research \& Development (R\&D) during the design process. Whereas, testing and revision is done along with the lecturing process, considering that this research is on research group's scientific which should integrate the research process with the improvement of learning quality. In addition, TVUPI has access address of http://tv.upi.edu, intended to support the management of message transformation in order to imaging UPI at national and international level.
\end{abstract}

Keywords: web streaming, model communication, tvupi, modern university

\section{Introduction}

Modern universities are characterized by their capability to adopt innovation products in the field of Information Technology to sustain the management functions so that their services become efficient. As has been researched and developed by Pablo Campos Calvo-Sotelo, CEU University of San Pablo, Spain (2010), under the terms concept of "Educational Campus" and its application in Spanish universities. Today's researchoriented efforts to build a modern university continue to be done; one of them is conducted by the university education Indonesia (UPI). Through the roadmap, the research has been developed and now is able to adopt cloud technology to support the process of communication and transformation of information needed in realizing its vision and mission to a leading and outstanding university.

Collaboration between research umbrella owned by UPI with Research and Development of Scientific Field Group (Scientific Group Research Program) has been running well, referring to research methods undertaken by lecturers who are researchers as well. A concrete evidence in this research has been developed as a research product in the form of development of Indonesian university education television (TVUPI), which developed through $R \& D$ where the testing and revision process is done by the researcher as a lecturer in the form of lectures. The courses, on the other hand, will improve the quality as the education communication course. Thus, both research processes and products with integrated processes and product of lectures are complementary and improving. From the implementation of this research, the product is expected to be able to answer the needs of communication model as a modern university that has been migrated to the world of digital communication media.

If it is analyzed based on the support of research and development of Scientific Group Research Program for web streaming by a team of researchers from UPI, there has been actually a lot of researches has been done, for example, a research held through the cooperation of UPI research team with USM

Received: March 28, 2017, Revision: April 25, 2017, Accepted: May 19, 2017

Print ISSN: 0215-8175; Online ISSN: 2303-2499. Doi:

Accredited by DIKTI. SK Kemendikbud, No.040/P/2014, valid 18-02-2014 until 18-02-2019, Indexed by DOAJ 
Malaysia (Hartati, et al (2013) which produces products in the form of Streaming web for Creative Learning. From the analysis of the research's result, there is an opportunity to develop more broadly in the context of fulfillment and strengthening the field of communication science's skills to produce a modern university communication model.

The process of developing streaming tvupi.edu is designed in a series of research in the form of lecturing process in the Education Communication course. Thus, at the end of the study and the lecture, it can produce prototype of TVUPI streaming, learning tools in the form of Semester Learning Plan (RPS), and Practicum Materials. Through the findings of this research, then the system that needs in building university imaging become more open.

\section{Research Methodology}

This research methodology was done by Research and Development (R\&D) approach, which covers 12 main steps of: (1) Literature Study and Preparation of Manuscript material web streaming tvupi.edu; (2) Baseline Data Analysis; (3) Formulation of Initial Design web streaming TVUPI; (4) Development of Enterprise Information System Database for storage of broadcast programs; (5) Development of Integrated Information Database Engine between broadcast delay and live broadcast; (6) Prototype Validation web streaming of tvupi.edu; (7) Online trial engine Database broadcast program of web streaming tvupi.edu with individual pages; (8) Entry and update process of tv.upi. edu program broadcast data based on the classification of broadcast category filter in accordance with the database system; (9) Trial ease, speed, web streaming access to tv.upi.edu from various regions; (10) Validation and Decimation web streaming tvupi.edu in the form of presentation and utilization of shared access; (11) Launching web streaming of tv.upi.edu, to manage news information that supports UPI imaging; (12) Publication and dissemination through books as well as national and international journals. All steps are adapted from Borg and Gall, (1989: 784-785).

The data collection instruments used include interview guidelines, observations, and test questions about learning outcomes on television subject matter in Education Communication courses. Data analysis technique used is Qualitative Technique (Milles and Huberman, 1993) to process data stream development of TVUPI and statistics simple (Furqon, 2010) to measure the improvement of student competence in Education Communication course.

\section{The form of Web streaming TVUPI as a Modern University Communication Model}

The results of field research indicate that web streaming TVUPI built on the basis

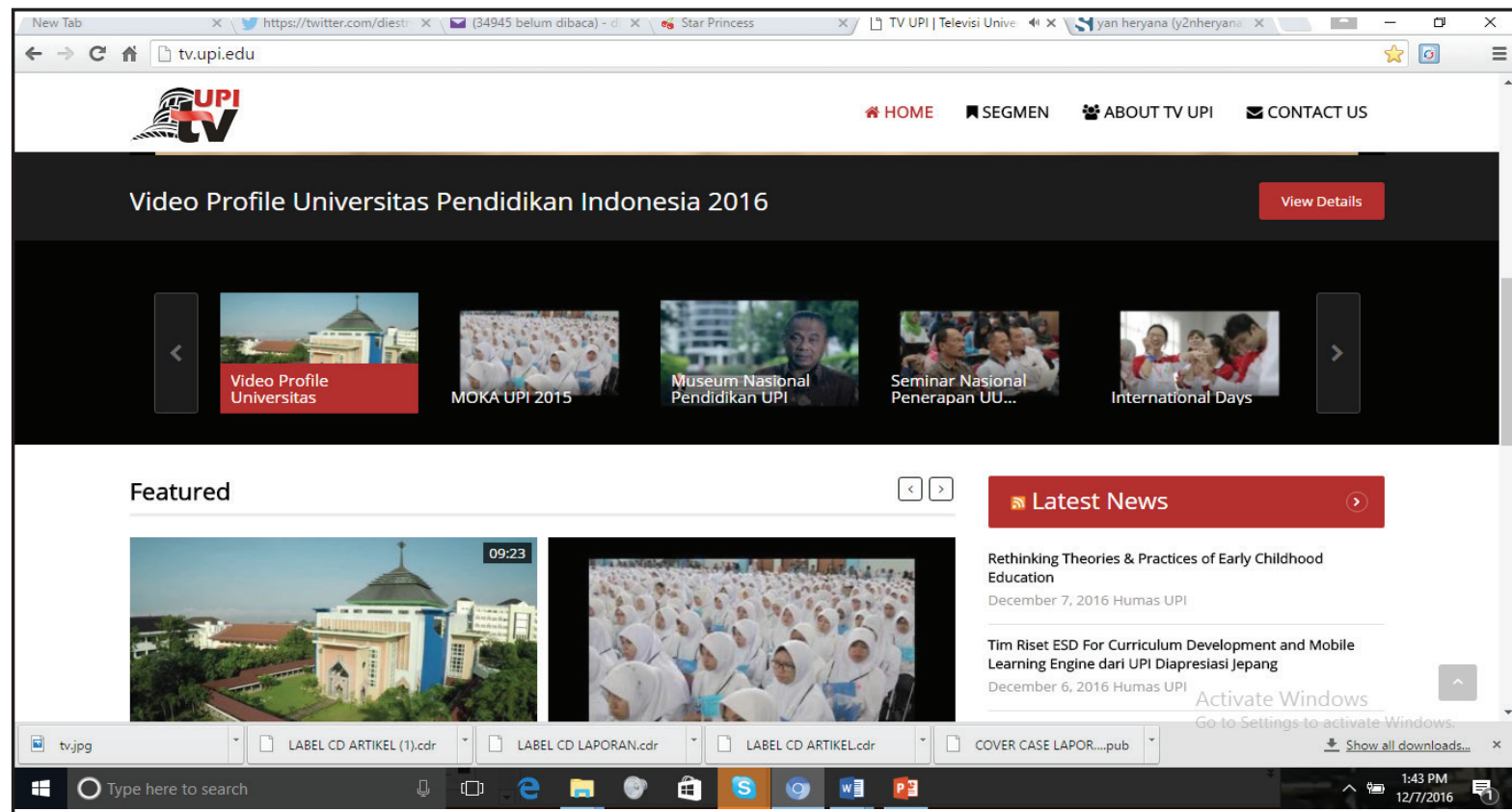

Figure 1.Portal of web streaming tv.upi.edu 
of cooperation with the Directorate of ICT that provides domain hosting, so the extension name of TVUPI ends with edu. Here is the view streaming TVUPI website that can be accessed on website address of http://tv.upi. edu, as it can be seen in Figure 1.

The Figure 1 shows that the news and information the viewer needs are accessible easily and quickly. Likewise, according to FGD results with TVUPI manager, it is stated that this web streaming technology enables TVUPI to quickly provide the needs of academic member information and wider national and international community. With the characteristics of digital and online coverage, it gives some information in the form of television shows based on web streaming. This modern campus communication model can be fulfilled through the utilization of cloud computing technology. In supporting the concept of modern campus, Steve Hann (2014: 20) in his research results, confirmed that: "(a) Ensure that cloud computing is available as an enterprisegrade service to enable effective adoption by our education customers; (2) Provide the infrastructure necessary to power both public and private clouds; (3) Jointly develop with education institutions (ministries of education, Higher education system, State Agency, etc) shared services models that drive extreme performance and efficiency.

In the context of this research, cloud computing has been used for storing a number of data in the form of TVUPI delay program broadcast files. Likewise, the requirement of infrastructure that supports the process of education services which can be proved in the lecture courses of education communication courses has been fulfilled. Through this TVUPI, UPI has been able to cooperate with other broadcasting institutions specializing in educational programs, such as PJTV, Custom of Ministry of Education and Culture. Thus, This study's finding on the concept of a modern university can be realized by UPI.

\section{Classification and TV shows' Data- base in the form of mobile streaming}

The show list for tv.upi.edu has still limited to UPI profile playback, as well as snippets of the latest recorded activities using mobile phone support, camera broadcast, and live recording with Teradex. The event includes segments of: (1) Education; (2) Entertainment; (3) Campus Activities; (4) Art and Culture; (5) UPI's Role in the Eyes of the
World; (6) UPI Cooperation and Partnership; (7) UPI Research; (8) UPI Publication Event. By going beyond mobile smartphone technology, accessing such events can be done easily, especially when it is used as a learning resource in lectures. The findings in the field show that all the events are able to support UPI's credibility and imaging in national and international community. For example, in a research presentation event in Japan (2016), respondents consisting of lecturers and directors of the $90 \%$ of regional campuses support TVUPI to continue broadcasting the event segment, either directly or broadcast delay.

These findings also show that the capacity of the database ready is still exist in the database Directorate of ICT. Furthermore, this database will be developed in accordance with the work program of Publications and Media which will migrate to Mobile Smart Digital system. Through mobile smart digital, TVUPI broadcasting can be utilized for the implementation of mobile learning about streaming television. In this case, Lingling Guo, Yu Fu, Xiaozhe Yin, Man Yuan, Zhang Fangzhou, Juntao Gao (2013: 159), insist that "M-learning is investigated and application is just experimenting." It also contains the meaning of the process that can be done freely to find a complete understanding, especially if it equipped with the development of web streaming TVUPI.

\section{Online sponsors for web streaming TVUPI}

Given the aspect of sustainability in the development, service and management of TVUPI services including all its activities require an adequate support system. The support is designed from both internal and external parties. The TVUPI educational program, in particular, have been supported by numbers of sponsors, which are: (a) Technology and Communication Central from Ministry of Education and Culture ; (b) PT Telkom Indonesia (telecommunication company); (c) Telkomsel; (d) West Java KPID; (e) BIFIT; (f) Chochodot (chocolate company); (g) The Bottles; (h) Al-Ma'sum Drinking Water Company; (i) TVRI Bandung (government's tv station); (j) Batik Garutan (traditional patterned-fabric); (k) Pesantren Daarut Tauhid (islamic school); (I) Rosda Karya Publisher. The acquisition of sponsors is very important, considering that television always provides an opportunity for the development of other fields as described 
by Fardiah (2007: i) that television is much "ogled" from various circles of politics, economics, social, culture, advertising, even the investors, so that this involvement will optimize the function of television as an educational medium. Based on that opinion, all partners and sponsors which will appear on web streaming tv.upi.edu are directed to the positive aspects and mutual benefit of both parties, especially in supporting the educational program presented by UPI as a modern campus.

\section{Development Process of Web stream- ing TVUPI: Preparation Product}

The result of analysis during the preparation stage of UPI TV web streaming development is the need for adequate server and database. To fulfill the power of web streaming, TVUPI will utilize the domain of the university, which is upi.edu. Web streaming is one of the alternative television needs in the campus environment that has grown today with the term of Community TV, where UPI is one of the universities that must already have a television. One of the foundations in the design of television making in the UPI Campus is the result of an analysis of the broadcast program based line that has been designed since 2007. Furthermore, in 2015, the existence of TVUPI still needs a follow-up.

This condition became the baseline in the development of Web streaming TVUPI conducted by research group program of Educational Communication Field. The widely utilization of upi.edu domain is a form of support for the development of web streaming TVUPI and the power of imaging university website.

The trial process is done 3 times, where the first trial is to the address the access and domain hosting in order to facilitate the viewers who are users of the academic community of UPI (lecturers, students, and educational personnel). The second trial is the content filling stage, where the test is done by presenting the profile of UPI. In the context of communication media in the form of television, certainly TVUPI will be able to educate all the audience. As explained by Santi Indra Astuti (2013: 45), that critical of the media is not only the task of professional educators, but also the media's job to educate the public about good and bad impressions. The media must cooperate with other social institutions to create an intelligent and moral generation.

\section{Validation Model of Web streaming tv.upi.edu by Academic Members of UPI}

The validation process is performed together with the development team of smart digital, as well as head of public relations office and another technical team. Likewise, other users are given an access address to view at http://tv.upi.edu. From viewers who are subject to opinion polls show that the presence of TVUPI is needed, especially from UPI leaders who really hope that this TVUPI can air to all over the region and even the world. Based on the validation results, a number of support systems for TVUPI have been prepared, ie policies covering, infrastructure, human resources, equipment, technology, sufficient budget, program planning, program content, program monitoring, sponsors or partners, ongoing development research, and promotion.

This preparation stage is very important considering the characteristics of tv.upi.edu developed by the university will certainly have a limited audience, but will be optimized the program in accordance with the needs of the intended audience. For example, the preparation of a broadcast program tailored to the characteristics of a university television. This effort is in line with what was put forward by Qiyun Chang (2014: 54), which explains that:

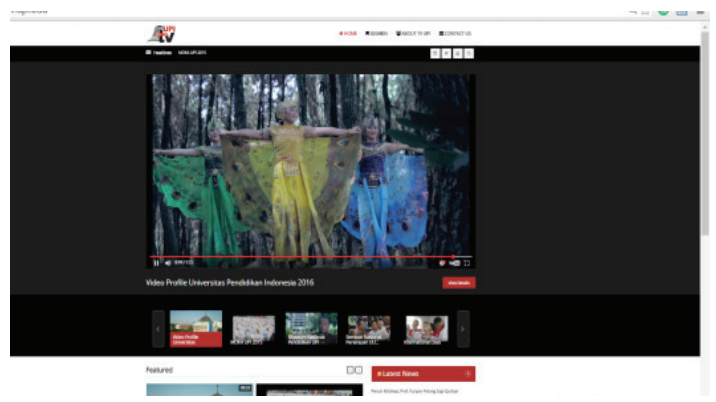

TV rating index as an objective indicator of quantitative, to some extent, reflects whether the viewers concern for the program or not. That is to say, TV ratings reflect the percentage of a population. From this percentage, it can be clearly seen how many people watch the TV. Therefore, the introduction of television rating index undoubtedly promote the competition among TV institutions, making television organizations pay more attention to meet the needs of the audience, gradually get rid of the past "communicators as the center" model, and began to focus on program communication effect.

Those opinions show that the appropriate program can increase the confidence of the audience segment, so that there are programs 
that will get the most audience and need to be improved, while the little must be improved more.

\section{Development of web streaming tv.upi.edu}

After conducting preliminary study in terms of conceptual strength of the system, technical, and easiness in developing and utilizing web streaming television, hence this research successfully developed tv.upi. edu with access address of http://tv.upi. edu/. Here are some scenes about tv.upi. edu web streaming view that can be watched asynchronous with the main appearance of the logo scene from tv.upi.edu as shown in the figure below.
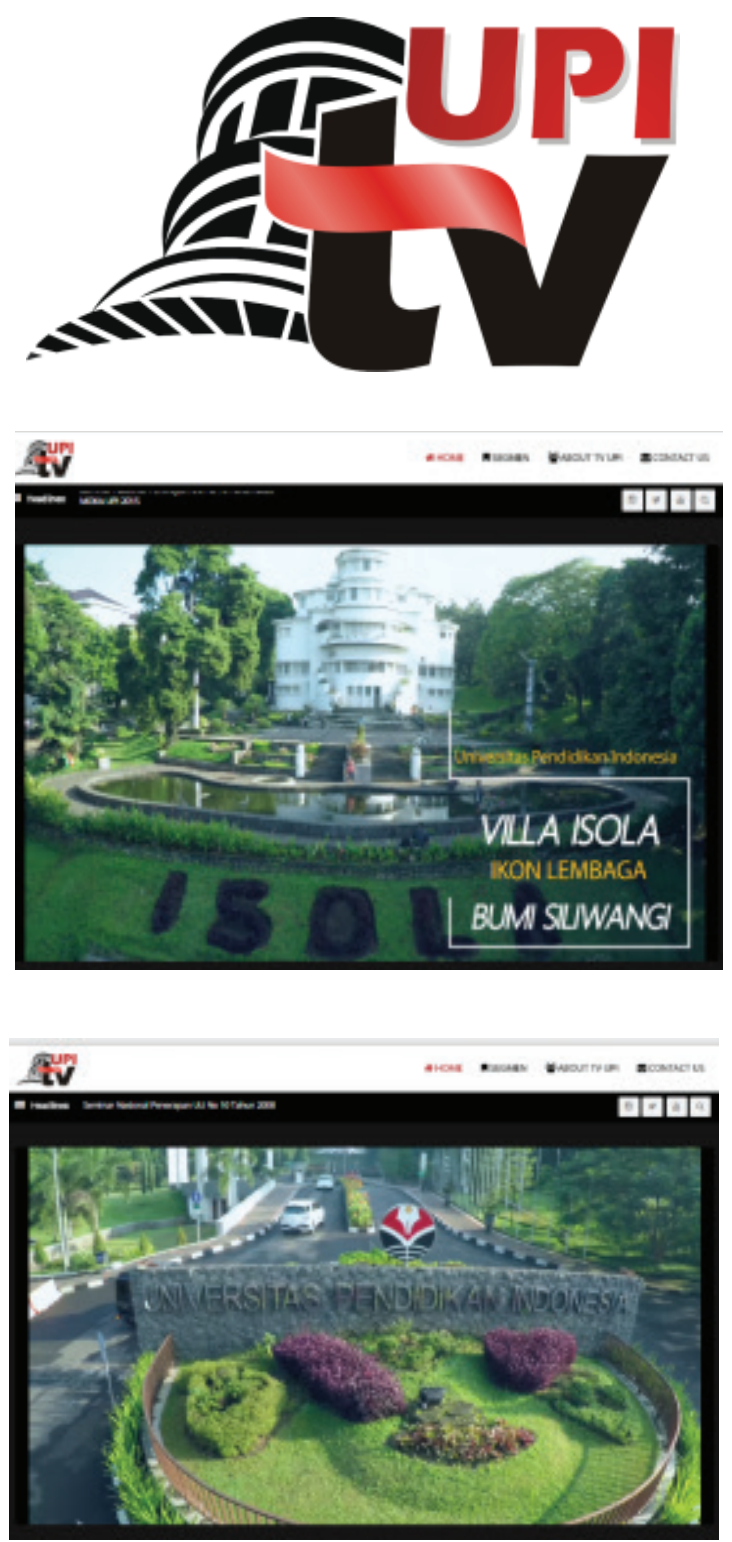

Figure 2. Some scene of web streaming tv.upi.edu

\section{Analyze, Design, and Developing website on tvupi.edu}

Design analysis and final website development assisted by the outsourcing directly become potential partners in developing web streaming TVUPI, which then will migrate it to Digital TV. The design emphasizes on the strength of citizens and the meaning of the TVUPI symbol. The data program to support this design will have 2 data support systems to be stored in support of broadcast delay or re-broadcast and program data for the needs of the live broadcast. This pilot phase was conducted at Shizuoka Japan live broadcast by involving Shizuoka University.

\section{Online Test Engine Database for web streaming of tvupi.edu}

As a continuation of the display design, TVUPI with web streaming support can eventually be installed via PlayStore supported by mobile smartphone devices. The results of this TVUPI test show the smart aspect means that it does not need many facilities and expensive but efficient enough and able to have broad broadcasting. The experiment was conducted by broadcasting directly the presentation of a research team from Japan to other team (by accessing it) in Indonesia, especially in UPI. The testing process can last for $2 \times 24$ hours nonstop. The viewing process is reviewed by broadcasting UPI profile with non live identity, and followed by live broadcasting of UPI research team presentation at Yoshisuke Kumano Shizuoka University Japan Laboratory (2016). These findings relate to living broadcast characters with the support of smartphones, which allow the academic community at the same time to access live tv.upi.edu. This finding is able to prove the opinion put forward by Xin Wang (2015: 2030) for the Applications of a Streaming Video Server in a Mobile Phone Live Streaming System. The opinion shows that accessing tv.upi.edu broadcasting can be done by utilizing smart digital television in mobile phone via video streaming facility.

\section{Data Entry Process for the category program of web streaming tv.upi.edu}

Data entry for the broadcast program category is performed by the admin or operator that will simultaneously monitoring the live broadcast or broadcast delay in accordance with the schedule of broadcasts that have been designed previously. The 
broadcast data categories include: (a) Event data of Event Spend Education Segment; (b) Data entry of Entertainment Event Segment; (c) Data entry of campus activity event segment; (d) Data entry of Art and Cultural Event Segment; (e) Data entry of UPI Events Segment in the Eye of the World; (f) Data entry of UPI Partnership Segment of Partnership and Partnership; (g) Data entry of UPI Research Events Segment; (h) Data entry of UPI Publication Event Segment. All the programs have been adapted to the character of the prospective audience, especially among lecturers, students and university employees. The efforts to categorize such broadcast data is worth doing because broadcast data can be stored well in a category that requires viewers from the academic community UPI to discuss it further as a form of superior assessment of broadcast programs. This pattern is adapted from the opinion of Maslawati Mohamad, Izyan Safwani Ismail, Normilah Wahab, Saripah Mamat (2016: 609), which stated that: " Producing a web TV program demands students to discuss and decide with their group members of what kind of programs they want to produce. Students need to come out with several ideas, suggestions, and opinions to make their TV show interesting and lively. Unfortunately, the students involved in this study felt they had little creativity."

\section{Trial of Ease, Speed, and Suitability of Engine System of Web streaming TVUPI}

As explained above, the support for accessibility aspects, speed and suitability of TVUPI web streaming engine is gained by the strength of mobile TV facility, which is to utilize the Mobile Streaming Technology ogy found on the smartphone. Thus, the access to TVUPI can be done anytime and anywhere. The aspect of the suitability for TVUPI web streaming is able to provide positive value for the students and lecturers who are always everywhere and not only in campus. The design of tv.upi edu with the suitability of the engine system especially related to the video-audio system in real-time of videoaudio streaming. This effort is in accordance with research findings from Chongyu Wei, Honglin Zhang (2014: 977) stating that "real time processing is easier than video. Since audio data have no key frames, only the audio head is needed to save. When the buffer is full, intercept the latest of several frames and move to the buffer beginning. Afterwards, the buffer gets fresh audio data again. "From that opinion, real time processing for audio video in TVUPI broadcast content will refer to the audio buffer rescue process, which is usually always late, that can be described as when the visuals have appeared, the sound is gone. Through real time audio support technology, it is expected that the sound and visual's quality will occur real time.

\section{Program Cooperation with Smart Digital Mobile}

Cooperative program activities have been conducted with a number of partners from national to private television shows. One of the programs of TVUPI partners that have been implemented during this research is TV Education from Ministry of Education and Culture. A number of special partner programs for teachers, students and lecturers, with students' program has achieved 20 episodes. The following is the result of cooperation with the topic of broadcast "Preparing Indonesia 2045 Generation of Gold Through the Curriculum 2013", which includes: (1) High School / Vocational Learning Teachers; (2) Concept of Local wisdom on Curriculum 2013; (3) The Role of Parents in the Implementation of Curriculum 2013; (4) Dissemination of Classroom Action Research; (5) Learning Expenditure of Curriculum 2013; (6) Assessment of Integrative Thematic RPP (teaching planning); (7) ICT application in the Implementation of Curriculum 2013; (8) Junior High School / MTs Teaching Practice; (9) Implementation of Curriculum 2013 on Indonesian language; (10) Assessment in Curriculum 2013; (11) Implementation of Curriculum 2013 On Mathematics Teaching; (12) Class Action Implementation; (13) Research on learning Mathematics; (14) Organization of Integrative Mathematics Materials in Elementary Schools; (15) Concept of Material Organization in Curriculum 2013; (16) Map of Integrative Mathematics Material at Elementary School; (17) Learning Planning in Curriculum 2013; (18) Organization of Competence-Based Subject Material; (19) Assessment on Indonesian Language Subjects; (20) Implementing of Authentic Assessment. Smart Digital Media has been done further cooperation by utilizing androidbased smartphone. This new technology is required by TVUPI for re-broadcasts, as well as lives broadcasts that can be watched easily, anywhere and anytime, which demand the user to have Android-based Smart Phone. Here is a mobile TVUPI view with Smart Digital Media support. 


\section{Smart Digital TVUPI Access Scheme and Portal}
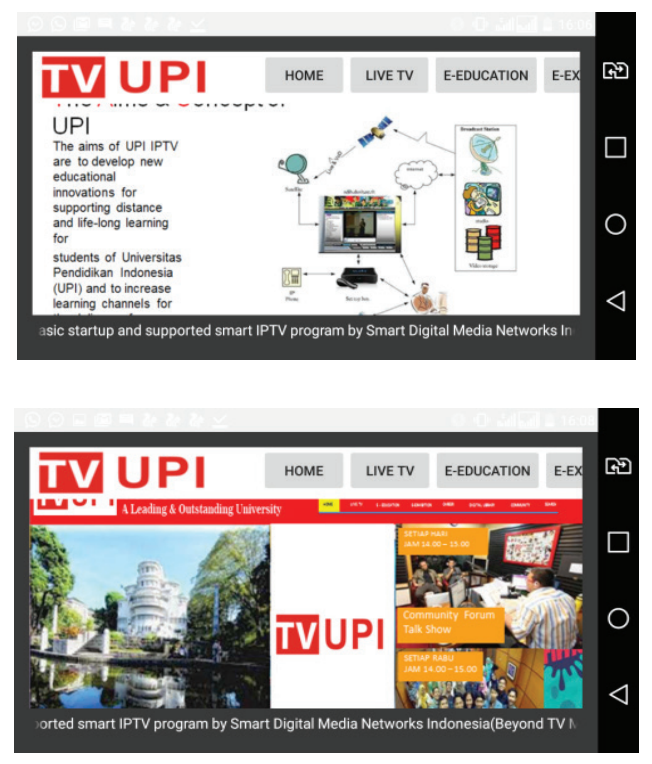

Structure and Design of TVUPI Studio
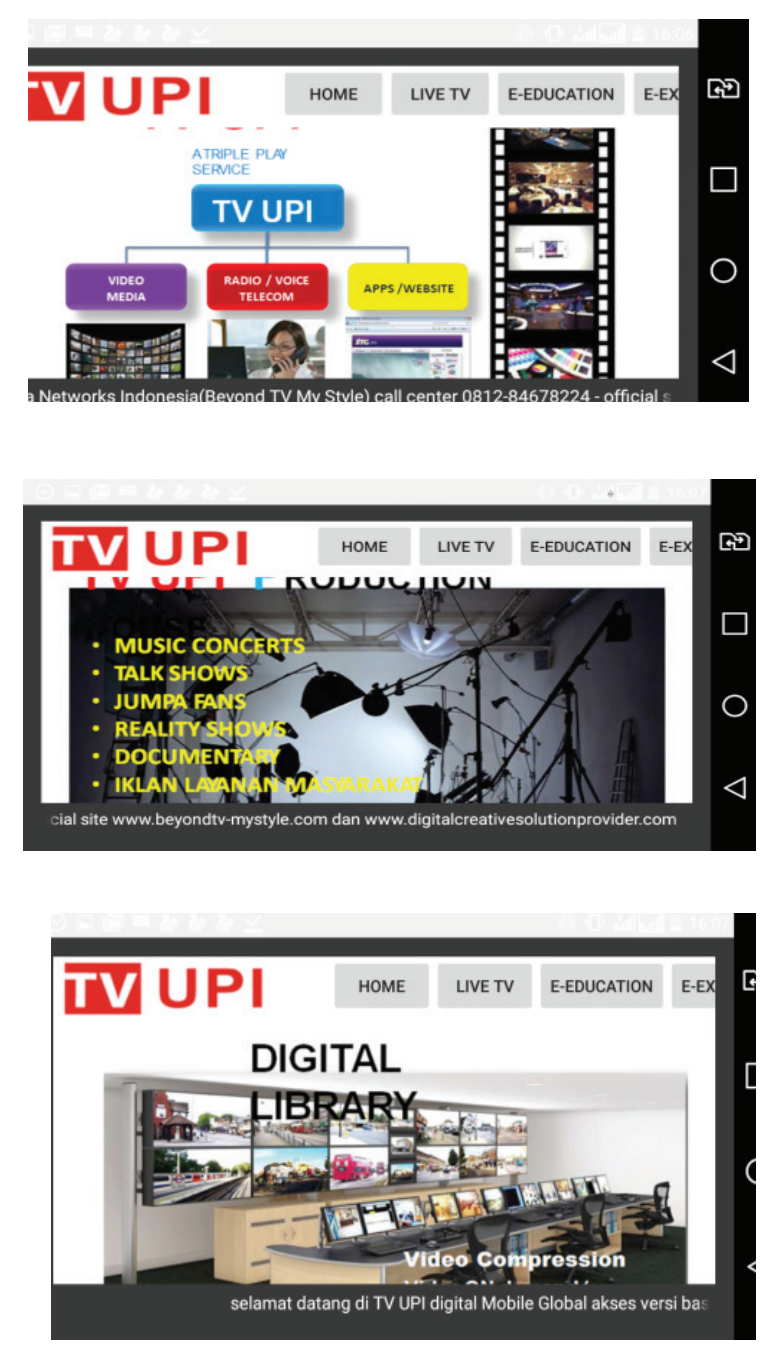

\section{Virtual Studio and Data Storage Pro- gram of TVUPI Broadcast}

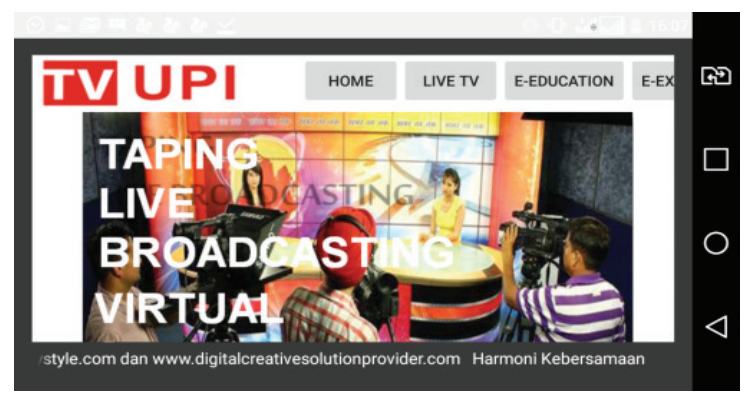

Figure 3. TVUPI on Scheme of Smart Digital Media

\section{Contribution of TVUPI Web stream- ing on Education and Learning}

The Model of Semester Program Plan (RPS) in the courses found in this study has been collaborated with the needs of student competence cultivation in the field of television communication studies, covering the subject matter of: (1) planting the basic concept of communication in general; (2) the concept of broadcasting; (3) broadcasting definition; (4) broadcasting model; (5) application of broadcasting products; (6) and its final use in television. The results of this study are very important in the aspect of Scientific Research Group which emphasizes on the correlation between background and research products with improvements in the quality of lectures. The model of Learning Program, which already in production, has been attached as a concrete result of this research. The process of compilation refers to the conditions and needs of how the students possess the experience to develop their thinking results in the world of television. The result of the lecture with the Model of Learning Program shows a synergy between the theory and practice of supporting students' competence, especially on (1) the theory of television; (2) web streaming; (3) digital television and; (4) TV streaming. The process can be initiated by a team of researchers who as well as teachers of educational communication.

In the model of learning program, it is found that this web streaming gives many advantages and advantages to be gained for the efficient development of broadcasting. This finding is supported by the opinion of Darmawan (2014: 33), which explains the advantages of web streaming, viewed from the increasing aspect of the number of users, is due to the aspect of interesting, easy, and 
complete mobile learning materials provided on the website, and also easily downloadable by them.

\section{Improvement of Television Compe- tency in Education Communication Course}

From website design to online, TVUPI can be accessed through the streaming website, result migration to PlayStore, and via Smart Mobile Phone. The findings of this design is sufficient to give a concrete explanation of what found by Darmawan (2014: 38), which explains that the phenomenon of increased access made by users to the website of this research findings is due to the main indicators of media in the form of symbols and images presented on each topic of mobile learning materials.

This study also analyzed the improvement of learning outcomes as a form of students' competence achievement in education communication courses, especially on a number of television material topics achieved by students majoring in Technology Education. The results can be seen on figure 4 .

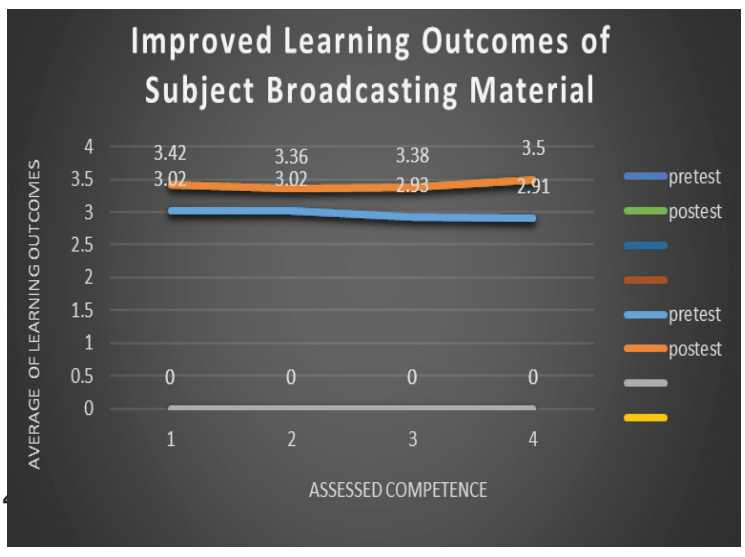

Figure 4. Improved Learning Outcomes Education Communication Course Topic of Broadcasting

Figure 4 shows that there is an improvement process for the competence of television material, includes; (1) The Theory of Television; (2) Web streaming; (3) TV Digital and; (4) TV streaming. The result is the influence of the lecturer who presents the teaching materials in the form of the practice of web streaming TVUPI development. Achievement of learning outcomes is student competence in the field of television theory increased by 0.40 points after they learn and dissect web streaming tv.upi.edu development. For the results of the sapphire web streaming study, students of educational technology are able to achieve an increase rate of 0.34 points, and for the learning results of Digital TV students are able to achieve the increase in learning results of 0.45 points. The highest learning achievement is achieved by the students of 0.69 points on the material of Streaming TV.

These findings prove the opinion of Steven Hann (2014: 10), which stated that the characteristics of modern universities which are seen from the "Student Cloud" aspect, which is "the new system will provide comprehensive student life cycle support for all types of institutions by coordinating interactions and mobile, and engagement across channels and devices."

In the web streaming system the lecture material can be viewed live or Re-broadcast so the material comprehension can be more intact. In this study, students are able to master the material on how to develop web streaming to produce a streaming television. The result is in accordance with the findings of similar research conducted by Jane de Almeida1, Maria Amelia Eliseo, Cicero Inacio da Silva, Helena Prates, Vic Von Poser, Brett Stalbaum, Nilton Gomes Furtado (2016: 2516), who explained that "The aim of this article is to describe a production tool of the real time video streaming tools which can, at the same time, transmit the content by using streaming features and also able to edit and select parts of the material, and generating a final product with coherent narrative for future use." That opinion states a primary value in a streaming video show owned by a number of tv.upi.edu of delayed broadcasts that can ultimately provide an opportunity to be edited, formatted, redrawn to fit the audience segment later. When the program is reloaded, the viewer of the public will have the opportunity to obtain information on the tv.upi.edu program so that the re-broadcast of the program can be stored in the cloud database system (Daniel Minoli, 2008), features UPI as a modern campus with TVUPI program. In relation to the characteristics of the modern university, the aspect of "Public Cloud" is reaffirmed by Steven Hann (2014: 14), who stated that

\footnotetext{
"Public Cloud Deployment, .... .cloud adoption in higher education and many other institutions to expand their use of public cloud services has been based on concerns over privacy, security, and the potential or perceived risks associated with multi-tenancy databases".
} 


\section{Conclusions}

From the results and discussion of research development that has been done, there are two important findings. First, web streaming ttv.upi.edu as a form of modern university communication model has been owned by UPI, with aims of improvement of education quality and the learning of communication education which is marked by the increase of students' competence in the education communication course. Systematically research products in the form of web streaming tv.upi.edu include: (a) Web streaming design to support TVUPI is done through interconnection TVUPI website with domain and hosting supported by directorate of ICT UPI; (b) The establishment of TVUPI Streaming Website is done through a collaborative management with public relations office of Publication and Media Management with access address http:// tv.upi.edu, and; (c) TVUPI Broadcast Program Classification is developed with coverage of Education, Cultural Arts, Campus Activity, UPI News, UPI Achievements, Student Activities, Research and Publication Education Business Education and Partnership Cooperation; (d) Development of the TVUPI Database is intended for the storage and retrieval of nonlive events and Live broadcast programs; (e) UPI Online Sponsorship is obtained through a system of providing business segments and partnerships for broadcast programs, which are Education, Cultural Arts and Achievements of UPI, Research and Publication Education and Live Talk show Cooperation Event; (f) TVUPI Production Process is conducted with reference to the development of television technology based on web streaming and smart digital media.

In the context of the contribution of educational communication through education and learning system, the findings of web streaming tv.upi.edu are supported by the learning of syllabus and Model of Learning Program of Education Communication Course from the analysis of students' competency needs on the subject of web streaming, television and digital broadcasting program. Likewise, the findings in the form of the Design and Development of Teaching Materials with the subject matter of "Theory and Practice of Television" as supplementary teaching materials which are done through cooperation between the research team and the lecturer's team of Education Communication, Department of Education and Curriculum, which cooperate with UPI Public Relation
Office. Through this research, there has been an increase in learning outcomes in the students of Education Technology Program, with the subject of Communication Education on (1) The Theory of Television; (2) Web streaming; (3) TV Digital, and (4) Streaming TV, performed within half a semester.

\section{Acknowledgement}

The writer as the researcher expresses the highest gratitude to LPPM UPI and UPI Rectorate Leader who has provided Research Financing with Scientific Research Group program. Through this Scientific Research Group program then there is an important product that has researchers so that one article to be published in this journal with accredited national reputations.

\section{References}

Campos, C. S. (2010). The concept of "Educational Campus" and its application in Spanish universities. International Publication of CELLE Exchange. New York: OECD (CEU University of San Pablo, Spain).

Chang, Q. (2014). The Development History of Chinese TV Audience Ratings and Its Critical Thinking. Advances in Journalism and Communication, 2014, 2, 52-57 Published Online June 2014 in SciRes. http://www.scirp.org/journal/ajc http:// dx.doi.org/10.4236/ajc.2014.22006

Darmawan, D (2011). Video Streaming. Bandung : Diskusi Web streaming for Creative Writing. Pelatihan Collaborative Research UPI-USM.

Darmawan, D. (2014). Peningkatan Aksesibilitas "3 M-Mobile Learning" sebagai Layanan Pendidikan. ).MIMBAR: Jurnal Sosial dan Pembangunan, Vol 30, No 1 (2014) . Halaman.38.

Fardiah, D. (2007). Format Tayangan Televisi Sebagai Media Pendidikan Kualitas Bangsa. MIMBAR: Jurnal Sosial dan Pembangunan. Volume 20, No. 4, Tahun 2004.

Furqon. (2010). Statistika Terapan untuk Penelitian. Bandung: Aphabeta.

Kumano, Y. (2016). Diskusi tentang Mobile Learning dan STEM. Shizuoka: Laboratorium Kumano.

Gall, M.D. and Wolter, B.R. (2003). Operation Research in Education. New York: Mc. Millan. Inc.

Guo,L., Fu,Y., Yin,X., Yuan,M., Zhang,F., Gao, J. (2013). Application of Mobile Learning System in Operating System Course. 
Communications and Network, 2013, 5, 157-160 http://dx.doi.org/10.4236/cn. 2013.52017 Published Online May 2013 (http://www.scirp.org/journal/cn)

Hann, S. (2014). Innovating for Education \& Research Excellence Oracle Cloud Solutions for the Modern Campus. New Yok: Oracle: Education and Research.

Hartati,T., Darmawan, D., Mulyasari, E. (2013). Video Streaming For Creative Writing At International Elementary School. Journal of Education and Learning. Vol.3 (1) pp10-25.

Jane de, A., Eliseo, M.A., Inacio da Silva,C., Prates,H., Poster, V.V., Stalbaum, B., Furtado, N.G. (2016). Sensemaking: A Proposal for a Real-Time on the Fly Video Streaming Platform. Creative Education, 2016, 7, 2515-2523 http://www.scirp. org/journal/ce.

Lankhorst \&Van.D.H.( 20007 ). "Modeling Enterprise Architecture with TOGAF. tersedia pada http://www. togaf-modeling.org/.

Maslawati, M., Safwani,I. I., Wahab,N.. Saripah, M. (2016). Medical Students' Challenges and Strategies in Producing Web TV Programs on YouTube. Creative
Education, 2016, 7, 604-618 Published Online April 2016 in SciRes. http:// www.scirp.org/journal/ce http://dx.doi. org/10.4236/ce.2016.74063.

Milles and Huberman. (1992). Analisis Data Kualitatif. Jakarta: UI-Press.

Minoli, D. (2008). Enterprise Architecture $A$ to $Z$ : Framework Bussiness Modeling, SOA and Infrastructure Technology. New York: CRC Press.

Santi, I.A. (2013). Patologi Kekerasan dalam Berita Televisi: antara Kontroversi dan Regulasi. MIMBAR: Jurnal Sosial dan Pembangunan, Vol. 29. No.1 (Juni, 2013): halaman: 41-48.

Wang, X (2015). The Content Security Mechanism of Smart TV Broadcasting Operating System. Open Access Library Journal, 2: e2030. http://dx.doi. org/10.4236/ oalib.1102030

Wei, C and Zhang, H. (2014). Applications of a Streaming Video Server in a Mobile Phone Live Streaming System. Journal of Software Engineering and Applications, 2014, 7, 975-982 Published Online November 2014 in SciRes. http://www. scirp.org/journal/ jsea http://dx.doi. org/10.4236/jsea.2014. 712085. 